\title{
Nonunion of Lesser Tuberosity Fracture in A 16 Years Old Teenager
}

\section{Marcelo Bao $^{1 *} \mid$ Antonio Barquet ${ }^{2}$}

*Correspondence: Marcelo Bao

Address: ${ }^{1}$ Ex Profesor adjunto de la Clínica de Traumatología y Ortopedia de la Facultad de Medicina de la República Oriental del Uruguay; ${ }^{2}$ Ex Profesor de la Clínica de Traumatología y Ortopedia de la Facultad de Medicina de la Re-pública Oriental del Uruguay

e-mail $\bowtie$ : marcelobao@adinet.com.uy

Received: 28 July 2021; Accepted: 11 August 2021

Copyright: (C) 2021 Marcelo B. This is an open-access article distributed under the terms of the Creative Commons Attribution License, which permits unrestricted use, distribution, and reproduction in any medium, provided that the original work is properly cited.

\section{ABSTRACT}

We report a case of a 16 years old adolescent who sustain a traffic accident with direct trauma in his left shoulder. He suffers an isolated avulsion of the lesser tuberosity of humerus. The lesion was missed and lead to a nonunion of the fragment. The interest of this report is to analyze this rare case his diagnosis, treatment and evolution.

Keywords: Lesser Tuberosity Fracture, Isolated Avulsion, Lesser Tuberosity Nonunion, Teenager Fracture. Case Report

\section{Introduction}

While the fracture of the lesser tuberosity of the humerus is frequently associated with posterior dislocation of the shoulder, its isolated fracture is extremely infrequent and frequently missed. The subscapularis muscle under considerable tension may avulse the lesser tuberosity onto which it inserts. nonunion of the lesser tuberosity is rare, especially in adolescents.

After a thorough review of the world literature (PubMed, Embase, Cochrane), we found n re-ported cases of delayed diagnosis or treatment of this injury (Neogi et al., 2013; Vezeridis et al., 2011) and n reported cases of acute isolated fractures of the lesser tuberosity (Teixeira et al., 2012; Tosun and Kesemenli, 2011; Ohzono et al., 2012; Provance AJ and Polousky, 2010; Dhawan et al., 2008; Hepp et al., 2008; Gruson et al., 2008; Alistair Pace, 2008; Levine et al., 2005; Hinov et al., 2002; Kanso and Bricout, 1998; Ogawa and Takahashi, 1997; Caniggia et al., 1996; Van Laarhoven et al., 1995; Paschal et al., 1995; Berbig et al., 1994; Le Huec et al., 1994; Kuroda et al., 1993; Kunkel and Monesmith, 1993; Earwaker et al., 1990; Berbig et al., 1994).

However we could not find any report of nonunion of an avulsed lesser tuberosity not related to posterior shoulder dislocation.

We report such a case and comment on the diagnosis and treatment of this condition. 
The aim of this manuscript is to bring attention to the importance of a correct diagnosis and treatment for this injury.

\section{Case Report}

On February of 2011 R.R a 16 years old male sustain a traffic accident while driving a motorcycle and bumping against a car, suffering a direct trauma in his left shoulder.

He was immediately assisted in a peripheral hospital where the AP and Lateral roentgenogram showed the fracture of the humeral lesser tuberosity (Fig. 1).

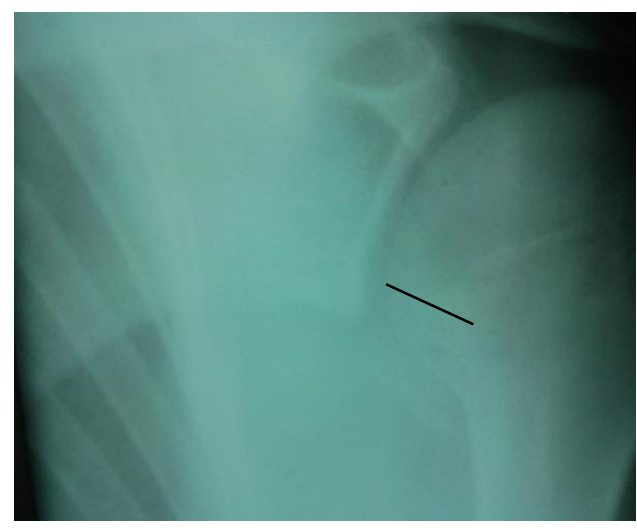

Figure 1: Rx Showed Humeral Lesser Tuberosity Fracture

He was immovilized in a sling and swath position for 3 weeks and then he began a rehabilitation plan with no further controls.

Four-month latter was admitted in the Institute and department of Orthopedics and Traumatology complaining of pain and functional limitation. Physical examination revealed no soft tissue swelling or bruise. the patient suffered of pain in the anteromedial aspect of the left shoulder. The active range of forward flexor was 110 degrees, abduction was 100 degrees, external rotation was normal whereas the internal rotation was $10^{\circ}$. Active extension and adduction was limited by pain to $10^{\circ}$. The passive range of extension and adduction were both 30. The strength of the affected shoulder was decreased in all the ranges of motion. Regarding preoperative clinical evaluation, the visual analog scale score was 5 points. DASH score was 57.5/100. Distal neurologic and vascular exam disclosed no abnormalities.

$\mathrm{AP}$ and lateral X. rays showed the gleno- humeral joint in normal position, thought the lesser tuberosity was displaced medially and anteriorly.

CT scans confirm the X. rays findings providing accurate information (Fig. 2 and Fig. 3) of the lesion and leading to the indication of open reduction and internal fixation of the fragment. 
As the patient was a minor consent for the surgery was requested from his legal tutors.

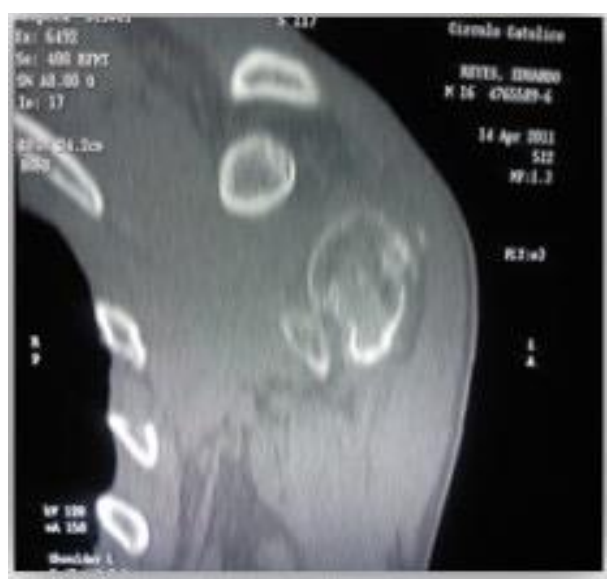

Figure 2: CT Scan Shows Non Union Fracture

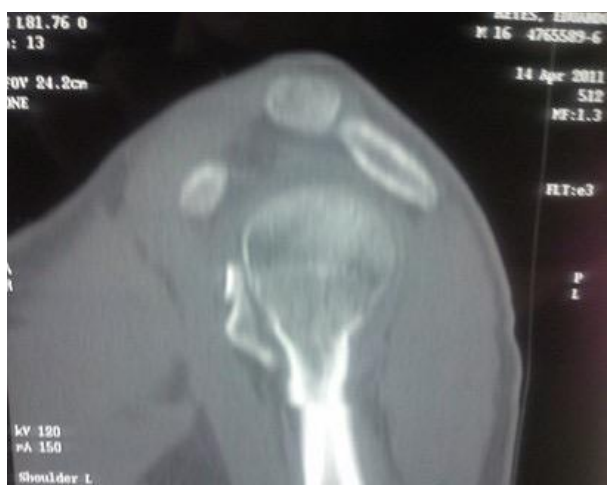

Figure 3: CT Scan Shows Non Union Fracture

This was performed using an anterior delto-pectoral approach, the fragment was identified, reduced and fixed using 2 cancellous 4.0 screws one of them supported with a washer (Fig. 4 and Fig. 5).

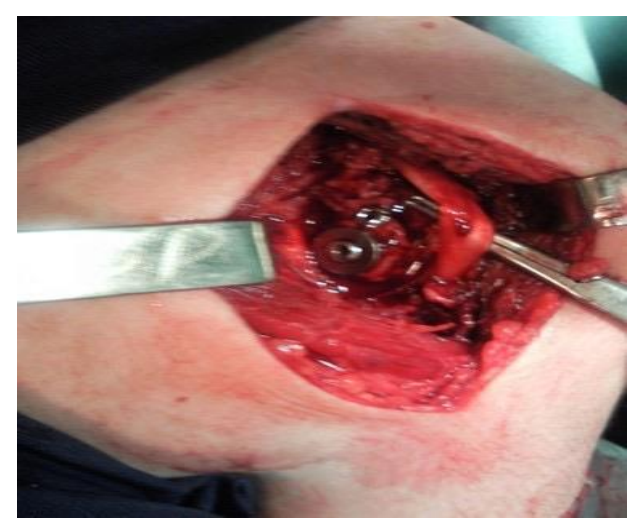

Figure 4: Fracture Fixed With 2 Cancellous Screws 


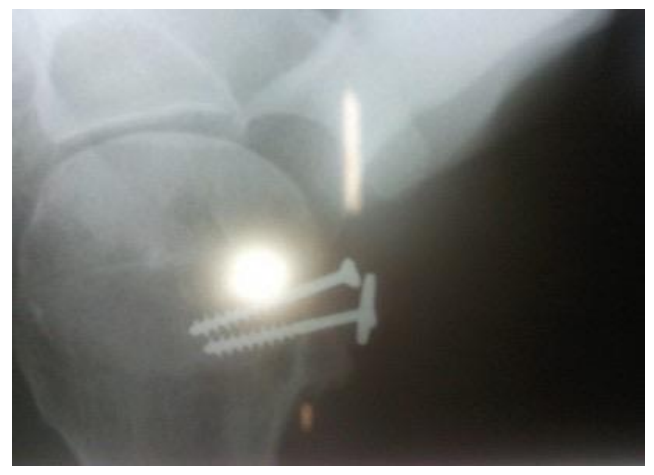

Figure 5: Rx Postoperative Control

After closure of the wound the upper limb was immobilized in the sling and swath position, during 4 weeks.

Thereafter a rehabilitation program was instituted with progressive motion of the shoulder during two further months.

At the latest follow up 2 years after surgery the patient recover full range of motion and strength of his upper limb.

\section{Discussion}

The interest of this report is to analyze a rare lesion and its evolution to a nonunion fracture with functional limitation.

The displacement of $1 \mathrm{~cm}$ of the lesser tuberosity fragment from its fracture bed and the fact that the patient did not seek for further assistance and continue to move his shoulder probably were the reasons of nonunion in this case.

The clinical signs were pain and weakness of internal rotation four months after injury in a teenager with high demand of his upper limb mainly in sport activities.

Open reduction and internal fixation of the lesser tuberosity was performed and led to a very good outcome.

In case like this, the diagnosis should be precocious leading to surgical treatment, in order to avoid mal union and nonunion. Reduction and internal fixation should be done immediately after the diagnosis of a displaced lesser tuberosity fracture to avoid these complications 


\section{References}

Alistair Pace MD. Isolated lesser tuberosity fracture of the humerus. Orthopedics (Online) 2008; 31: 94.

Berbig R, Keller H, Metzger U. Isolated fracture of the lesser tuberosity of the humerus: case reports and review of the literature. Revue de Traumatologie et D'assicurologie: Organe Officiel de la Societe Suisse de 1994; 87: 159-168.

Berbig R, Keller H, Metzger U. Isolated fracture of the lesser tuberosity of the humerus: case reports and review of the literature. Zeitschrift fur Unfallchirurgie und Versicherungsmedizin: Offizielles Organ der Schweizerischen Gesellschaft fur Unfallmedizin und Berufskrankheiten= Revue de Traumatologie et D'assicurologie: Organe Officiel de la Societe Suisse de... 1994; 87: 159-168.

Caniggia M, Maniscalco P, Picinotti A. Isolated avulsion fracture of the lesser tuberosity of the humerus. Report of two cases. Panminerva Med 1996; 38: 56-60.

Dhawan A, Kirk K, Dowd T, Doukas W. Isolated avulsion fracture of the lesser tuberosity of the humerus in an adult: case report and literature review. Am J Orthop (Belle Mead NJ) 2008; 37: 627-630.

Earwaker J. Isolated avulsion fracture of the lesser tuberosity of the humerus. Skeletal Radiol 1990; 19: 121-5.

Gruson KI, Ruchelsman DE, Tejwani NC. Isolated tuberosity fractures of the proximal humerus: current concepts. Injury 2008; 39: 284-298.

Hepp P, Theopold J, Engel T, Marquass B, Düsing T, Josten C. Lesser tuberosity avulsion in combination with multifragment fracture of the greater tuberosity. A rare entity at the proximal humerus. Der Unfallchirurg. 2008; 111: 628-631.

Hinov V, Wilson F, Adams G. Arthroscopically treated proximal humeral fracture malunion. Arthroscopy: The Journal of Arthroscopic \& Related Surgery 2002; 18: 1020-1023.

Kanso I and Bricout JM. Isolated avulsion fracture of the lesser tuberosity of the humerus. Apropos of a case. Rev Chir Orthop Reparatrice Appar Mot 1998; 84: 554-557.

Kunkel SS and Monesmith EA. Isolated avulsion fracture of the lesser tuberosity of the humerus: a case report. J Shoulder Elbow Surg 1993; 2: 43-46. 
Kuroda T, Go G, Ojima S, Nishi S, Mizuno K. Isolated avulsion fracture of the lesser tuberosity of the humerus: a case report. J Shoulder Elbow Surg 1993; 2: 221-224.

Le Huec JC, Schaeverbeke T, Moinard M, Kind M, Chauveaux D, Le Rebeller A. Isolated avulsion fracture of the lesser tubercle of the humerus in children. Acta Orthop Belg 1994; 60: 427-429.

Levine B, Pereira D, Rosen J. Avulsion fractures of the lesser tuberosity of the humerus in adolescents: Review of the literature and case report. J Orthop Trauma 2005; 19: 349-352.

Neogi DS, Bejjanki N, Ahrens PM. The consequences of delayed presentation of lesser tuberosity avulsion fractures in adolescents after repetitive injury. J Shoulder Elbow surg 2013; 22: e1-5.

Ogawa K and Takahashi M. Long-term outcome of isolated lesser tuberosity fractures of the humerus. J Trauma 1997; 42: 955-959.

Ohzono H, Gotoh M, Mitsui Y, Kanesaki K, Okawa T, Higuchi F, Nagata K. Isolated fracture of the lesser tuberosity of the humerus: a case report. Kurume Med J 2012; 58: 131-133.

Paschal SO, Hutton KS, Weatherall PT. Isolated avulsion fracture of the lesser tuberosity of the humerus in adolescents. A report of two cases. JBJS. 1995 Sep 1;77(9):1427-1430.

Provance AJ and Polousky JD. Isolated avulsion fracture of the subscapularis tendon with medial dislocation and tear of biceps tendon in a skeletally immature athlete: a case report. Curr Opin Pediatr 2010; 22: 366-368.

Teixeira RP, Johnson AR, Higgins BT, Carrino JA, McFarland EG. Fly fishing-related lesser tuberosity avulsion in an adolescent. Orthopedics 2012; 35: e748-751.

Tosun B and Kesemenli CC. Isolated avulsion fracture of lesser tuberosity of the humerus: Review of the literature and report of two cases. Int J Shoulder Surg 2011; 5: 50-53.

Van Laarhoven HA, Te Slaa RL, Van Laarhoven EW. Isolated avulsion fracture of the lesser tuberosity of the humerus. Journal of Trauma and Acute Care Surgery 1995; 39: 997-999.

Vezeridis PS, Bae DS, Kocher MS, Kramer DE, Yen YM, Waters PM. Surgical treatment for avulsion injuries of the humeral lesser tuberosity apophysis in adolescents. J Bone Joint Surg Am 2011; 93: 18821888. 